\title{
Illusory Control: Female’s Sexuality and Male’s Fantasy in The Changeling
}

\author{
Chien-hang Liu \\ Xinyang Normal University, Xinyang, China
}

\begin{abstract}
Thomas Middleton and William Rowley's The Changeling enacts an astonishment on the stage to the audience about the protagonist Beatrice-Joanna's down fall—the noble lady being straightly encroached by her desire and being manipulated by the obscene servant De Flores, who, by means of rape, controls her body and finally destroys her. My article attempts to explore male's expectations and their power over female's sexuality with Jacques Lacan’s psychoanalytical approach. Moreover, it will elaborate that Beatrice-Joanna’s tragic outcome is not only contributed by her murder and moral degradations, but also, before her transgression being committed, her body has already been regulated by the patriarchal power in the Renaissance society-either she is valuable in the marriage market with her chastity or she is condemned by losing it. Also, the science of medicine employed to test virginity represents the male's methodological hegemony and anxiety in facing the unknown of a female's chastity. For the fantasy always regulating the male's power structure over female's body, the real manipulation over female sexuality is doomed to be an illusion.
\end{abstract}

Keywords: fantasy, jouissance, sexuality, virginity/chastity

\section{Introduction}

Thomas Middleton and William Rowley's The Changeling is a Jacobean tragedy, giving out an astonishing effect of the theater about a noble woman's down fall that brings her own calamity. The noble lady is straightly encroached by her desire and manipulated by the obscene servant De Flores, who, by means of rape, controls and finally destroys her. In other words, the degraded servant, as the name suggests “deflower,” deprives Beatrice's maidenhood and secretly possesses her as his whore. How does sexuality become the main factor to manipulate the unlucky Beatrice and finally destroy her? With the horrifying outcome, the play reflects the male's attitude, revealing both his fantasy and anxiety, toward the female sexuality. The paper attempts to expose the aspect on female sexuality and explicate the power relationship between the two sexes. Beatrice's degradation is not only because of her trespass over moral boundaries (of murder and adultery) but also of male's expectations in the patriarchal society that chastity is an ideology, exercising its power to control female sexuality. Her tragedy suggests a doom of failure to escape the domination of male's expectations: either she assumes to her father's order, marrying to the first fiancé Alonzo, or rebels it. Both ways lead to unhappy results: either she cannot choose her mate, or she is condemned from her own resistance.

Chien-hang Liu, docotral lecture of the School of Foreign Languages, Xinyang Normal University. 


\section{Female’s Sexuality}

In European Renaissance, the female virginity is a field where the patriarchal power extends, for the unmarried daughter is generally regarded as a property of the family which gives chance to climb the social ladder and status in the marriage market. "For women and (at least theoretically) for men as well, marriage was the only socially sanctioned path along which sexual desire could find fulfillment” (Engle, 2002, p. 1593). In this sense, a lady's maidenhood is attached with indispensible value in marriage market. Further, Engle argues that "The Changeling richly represents institutions of social control run by fathers, husbands, and masters in order to prevent or contain change” (Engle, 2002, p. 1594). To treat the virginity of a daughter as a treasured property, the family must carefully keep it intact. "In a society where status and access to legal rights depended on the ownership of property, the matter of law was settlement of property disputes” (Burks, 1995, p. 765).

However, this play is about change and loss: raped by De Flores, Beatrice loses her virginity before marriage. And the misfortune starts with the daughter's disobedience against the father's will:

VERMANDERO He shall be bound to me as fast as this tie

Can hold him; I'll want my will else.

BEATRICE [aside] I shall want mine if you do it. (Middleton, 2002, p. 1591)

At the time she falls in love with Alsemero and decides to get rid of the fiancé her father assigned. It is as Engle notes: "Beatrice's pursuit of her desires leads her to conceive and initiate a series of crimes that eventually destroys her" (Engle, 2002, p. 1594). Succumbing to her desire, Beatrice what transgresses is not only her father's will but the moral law. Her dashing desire and bold disobedience lead her into both a villain and a victim because her desire is neglected and her body enclosed. Her desire and body in this play is, of course, relative to sexuality, which is dominated by the masculine regulations. But what does Lacan say about sexual relationship? “[I]t is impossible to found a sexual relationship" (Lacan, 1999, p. 9). The notion doesn't suggest that the authentic sexuality steadily relies on homogeneous one but, rather, indicates the fantastic relations of the subject over the object, self over the other. "[T]here's such a thing as One" (Lacan, 1999, p. 5): the wholeness is structurally impossible that it is the logic of the "not-all” or of exception constitutive of the universal. Slavoj Žižek turns this exception of the "not-all” into the notion of symptom:

Previously a symptom was a pathological formation to be (ideally, at least) dissolved in and through analytic interpretation, an index that the subject had somehow and somewhere compromised his desire, or an index of the deficiency or malfunctioning of the symbolic Law that guarantees the subject’s capacity to desire. (Žižek, 2002, p. 58)

When the symptom stands for the malfunction of the symbolic, the subject's masculine structure would meet its deficiency, a traumatic void in its core. Therefore, the sense of desire merely leads the subject to aim at its gap in the One qua signifier. When the One stands for the discourse of masculine subject, in this sense, the very desire of the subject reveals the very lack or "not-all” in the subjective core. Žižek elucidates: "Sexual difference is not a firm set of 'static' symbolic oppositions and inclusions/exclusions ... but the name of a deadlock, a trauma, an open question—something that resists every attempt at its symbolization (Žižek, 2002, p. 61). Sexual differences, in this perspective, correspond to Lacan's Real, the chaotic position, which always eludes the symbolic qua masculine discourse to capture and define. In this sense, the female's sexuality reflects the incomprehensible part of male's imagination, a very traumatic part of male sexuality. 


\section{Male's Fantasies}

But if the female's sexuality remains an enigma, how can we acknowledge the difference of the male's sexual pleasure from the female's? Lacan tells us: “...that woman knows nothing of this jouissance” (Lacan, 1999, p. 75) because she is not-whole, the fracture of male discourse, that "she has a supplementary jouissance" (p. 75). What Lacan tries to say is that woman is outside the discourse of male's enjoyment, and what she experiences is the "not-all," a pleasure of exception beyond the discourse. It is as Žižek expounds that "there are subjects for whom access to jouissance is much more closely linked to the domain of the Other's discourse" (Žižek, 2002, p. 59). While male indulges himself into masturbatory jouissance, female finds jouissance "at the level of the Other (symbolic order)" (p. 59). Female's jouissance is not only the enjoyment in words but in the sense of alienation - "it reside entirely in her awareness that she is enabling the Other to enjoy" (p. 60). In this sense, Žižek regards the female orgasm belongs to the field of bodily sphere, of its sexuality relating to human evolution —an experience playing the roles of the ontological proof of God (Žižek, 2017, pp. 143-144). If the full female orgasm is seen as “a split in the One-God” (p. 144), doesn't male enface such experience as the unfathomable $\mathrm{X}$, which represents Lacan's Real in human sexuality?

When De Flores picks up one of Beatrice's dropped gloves, he says:

Here's a favor come, with a mischief! Now

I know she had rather wear my pelt tanned

In a pair of dancing pumps than I should thrust my fingers

Into her sockets here. I know she hates me,

Yet cannot choose but love her. (Middleton, 2002, p. 1597)

Here, De Flores' wishful thinking is related to the masturbatory imagination where "fingers" imply the phallic function that enables the symbolic order to operate. What symbolic order is activated here? It is courtly love.

DE FLORES Put it not from me;

It's a service that I kneel for to you. [He kneels.]

BEATRICE You are too violent to mean faithfully.

There's horror in my service, blood and danger;

Can those be things to sue for? (Middleton, 2002, p. 1594).

The dialogue of the lady and servant awkwardly imitates courtly love-Beatrice acquires him to murder her fiancé appointed by her father, and De Flores sensually craves for the lady's body. However, the young lady is wrong about the degraded servant when she thinks: "Belike his want are greddy, and to such/ Gold tastes like angels' food” (Middleton, 2002, p. 1593). Courtly love is regulated by “the master's discourse, and in relation to whom the lady is entirely... a subject - the only way to elegantly pull off the absence of the sexual relationship" (Lacan 69). It is De Flores' wishful thinking that he expects Beatrice’s erotic reward by saying: "Come, kiss me with a zeal now" (Middleton, 2002, p. 1601). De Flore's expectation is a masturbatory indulgence in the form of courtly love concealing obscene lust. What supports De Flores' sexual energy to Beatrice is his fantasy:

...I'm sure both

Cannot be served unless she transgress. ...

She spreads and mounts then like arithmetic-

One, ten, a hundred, a thousand, ten thousand-

Proves in time sutler to an army royal. (Middleton, 2002, p. 1596) 
Isn't it the male's speculation on the female sexuality that once she lets out her desire by transgression, she will climb the erotic pleasure higher and higher? Narcissistically fantasying himself as a knight, De Flores is caught in a masturbating fantasy about bringing sexual pleasure to Beatrice. It corresponds to Lacan's elucidation - female’s supplementary jouissance — a pleasure in pain supports and reinforces male’s desire.

Also, De Flores declares that if her "virginity” were not perfectly enclosed, he would have no wish to ravish her (Middleton, 2002, p. 2009). Judith Haber elucidates that “in a culture in which women are blamed for arousing male desire, even the purest woman is viewed as possibly complicit in her own ravishment” (p. 82). In this sense, women are responsible for arising men's desire, even if they are unaware of it. According to Lacan, Female knows nothing of jouissance, but a supplementary one which enables the male to enjoy. ${ }^{1}$ Fantasying himself to bring pleasure to Beatrice, however, De Flores’ sexual expectations, enabling himself to indulge in the masturbatory structure, proffers her not enjoyment but fright-Beatrice says, "This fellow has undone me endlessly!/ Never was bride so fearfully distressed” (MIddleton, 2002, p. 2015). It is as Haber tells us: “to be 'undone' is literally to be unperfected, deprived of closure, made forever 'endless'” (p. 81). Being ravished by the servant she loathes, she experiences an intensifying fear as a bride goes through. "The public and private languages,” Michael Andrews argues, “demonstrate both sides of the rhetoric of Courtly Love, the idealized language appropriate to wooing, and the private language reflecting physical corruption” (Andrews, 1971, p. 373). Here, the private language indicates De Flores' seduction by means of rape. Beneath her apparent corruptions, the discourse of patriarchal has always-already formulated her "as an object to be claimed and possessed” (p. 374). Since courtly love, to Lacan, is a drive circumvents the sexual relationship, its route encompasses the void of femalesexuality. To idealize the spiritual aspect of female, the suitor employs the lofty language (a public language) to symbolize male’s jouissance. But the discourse of symbolic usually inaccurately imposes on the reality of its subject that it is, as Beatrice tells Alsemero:

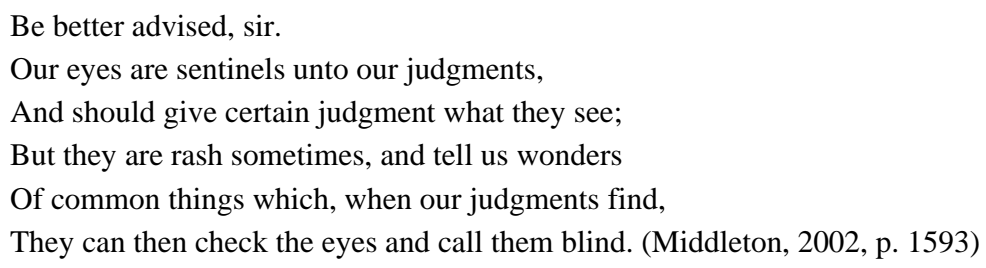

What the play implies might be: since the women are "the changeling," the appearance our eyes can be deceitful. Žižek tells us that the true voice of objects is mute, "stuck in the throat, and what effectively reverberates is the void” (Žižek, 1996, p. 93). In this sense, we are unable to afford the silence and the void so that we need sound to symbolize the voice of the object:

"Why do we listen to music?”: in order to avoid the horror of the encounter of the voice qua object. What Rilke said for beauty goes also for music: it is a lure, a screen, the last curtain, which protects us from directly confronting the horror of the (vocal) object. (Žižek, 1996, p. 93)

Our incapability of confronting the void of the object's voice is like the male's impotence to cope with the unknown female sexuality. Thus, if the female’s sexuality remains an enigma or void to the male's perceptions,

\footnotetext{
${ }^{1}$ Lacan notes: “...namely, that woman knows nothing of this jouissance... If she simply experienced it and knew nothing about it, that would allow us to cast myriad doubts on this notorious frigidity” (On Feminine, p. 75).
} 
Alsemero's vials of testimony stand for the interpretation, symbolizing the sexual symptom of the female sexuality. The knowledge of science is “The Book of Experiment, / Called Secrets in Nature” (Middleton, 2002, p. 1970). Beatrice firstly notices the Glass $C$ which tests a woman's pregnancy: "and if she be with child, she sleeps full twelve hours after; if not, not” (Middleton, 2002, p. 1602). And secondly, she finds the Glass M, which tests a woman's maidenhood, for a virgin will reveals three symptoms: "'twill make her incontinently gape, then fall into a sudden sneezing, last into a violent laughing, else dull, heavy and lumpish” (Middleton, 2002, p. 1972). Beatrice feels herself no effects by taking the medicine, but Diaphanta, after she takes it, produces all the appropriate symptoms in the prescribed sequence.

The question is-if a virgin takes the medicine, what do the effects mean? The first stage of gape, Marjorie Garber argues that it is Dyspnoea, shortness of breath. "Not always, perhaps, with open mouth—but to 'gape' is also to gasp, with pain or pleasure” (Garber, 1996, p. 352). And for sneezing, it is deflected or displaced physiologically into convulsions, which refer to a healthy completion of labor. "In Harvey's description these convulsions,” Garber elucidates, “'roused” by the sternutatory, appear to mimic the involuntary spasms of sexual orgasm" (Garber, 1996, p. 353). It is worth to notice that the woman feels nothing - "It is the (male) doctor who produces these effects, without her conscious participation, or ever her knowledge” (Garber, 1996, p. 353). The symptoms of gape and sneeze are through the ejaculation of nose, which usually relates to sex. And the last stage on laughing and lumpish connects to sexual orgasm and the subsided. All the symptoms manifest on a virgin's body reflect the male's fantasy on the female sexuality when she is on the first sexual experience. By means of science, the "public language" of medical test shares the fantastic structure with De Flores' "private language": while the medicine forces a virgin with the three stages of effects, De Flores speculates that a lady will climb a high orgasm after she transgresses. Does Beatrice-Joanna, however, really achieve her sexual pleasure after being ravished? Michael Andrews tells us: "The rhetorical unity of the play, then, amounts to the silencing of Beatrice-Joanna” (Andrews, 1971, p. 373). What does the silencing mean? Doesn't it indicate that the female sexuality is actually an exception, a "not all" in Lacanian term, a void to male's comprehension? The symptoms on Alsemoero's Glass M are the fact that it produces, or is expected to produce, orgasmic effects in virgins. They are not "real" effects of women's sexual pleasure but the product formulated by the will of knowledge/power, expectations, and fantasy. In this sense, "glass $\mathrm{M}$ - the detection of a virgin-represents the fruits of a male fantasy, the fantasy of the male doctor/lover as at once the inventor and the scientific investigator of female pleasure” (Barber, 1996, p. 357).

Beatrice learns the effects from Alsemero's pharmacy and also learns how to fake it. When Alsemero offers her the liquid of Glass M to drink, she says: “I'm put now to my cunning. Th'effects I know,/ If I can now but feign 'em handsomely” (Middleton, 2002, p. 1605). She follows the description to yawn, sneeze and then laugh. What she exhibit fits into her lover's fantasy and expectation. To Beatrice, Aslemero says: "My Joanna!/ Chastes the breath of heaven, or morning's womb/ That brings the day forth: thus my love encloses thee" (Middleton, 2002, p. 1607). Beatrice's enacts the gesture succumbs to the patriarchal power: her performance corresponds to her father's expectation of being a virgin and also submits to what Alsemero wishes to perceive- an expectation formulated by his fantastic illusions that is enforced by his scientific study of human nature. Therefore, Alsemero's "thus my love encloses thee” (Middleton, 1608, p. 151) becomes the very gesture lulled by the appearance of Beatrice's fake. The Glass M becomes the gadget, the detection of a virgin, "represents the fruits of 
a male fantasy, the fantasy of the male doctor/lover as at once the inventor and the scientific investigator of female pleasure" (Graber, 1996, p. 357).

Also, the Glass M reflects male’s anxiety toward the female symptom. Previously a symptom was a pathological formation to be (ideally, at least) dissolved in and through analytic interpretation, an index that the subject had somehow and somewhere compromised his desire, or an index of the deficiency or malfunctioning of the symbolic Law that guarantees the subject’s capacity to desire. (Žižek, 2008. pp. 305-306) This symptom is where male's failure — the gadget betrays his inability to perceive the real of female's sexuality, not to mention to control it. The symptoms of the test divulge male's malfunctioned capacity to preserve the virginity of a bride and chastity of a wife.

The theme of the cockle husband also reveals on Alibius that doubts his wife's chastity, out of the fearing on himself old and his wife too young:

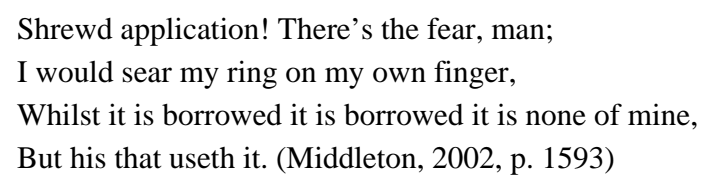

The discrepancy in age incites the sexual anxiety that not only motivates Alibius to keep his wife enclosed but also to spy her in his absence. "The lesson of the subplot is not so much that some women are capable of chastity, but that nothing men can do will guarantee women's honesty” (Bruk, 1995, p. 778). In this sense, both Beatrice-Joanna's virginity and Isabella's chastity become Lacanian "object petit $a$," the object cause of desire. Beatrice's maidenhood is the very cause of the object which De Flores desires to ravish, and Alsemero worries to test. Both of them inevitably fantasize the core as an object $a$ in her sexuality."Fantasy is then to be conceived as an imaginary scenario the function of which is to provide a kind of positive support filling out the subject's constitutive void" (Žižek, 2008, p. 254). Of course, a daughter's virginity is also valuable to her family in negotiating marriage. Likewise, Michel Foucault elaborates the relation of sexuality and marriage:

It will be granted no doubt that relations of sex gave rise, in every society, to a deployment of alliance: a system of marriage, of fixation and development of kinship ties, of transmission of names and possessions. ... The deployment of alliance is built around a system of rules defining the permitted and the forbidden, the licit and the illicit, whereas the deployment of sexuality operates according to mobile, polymorphous, and contingent technique of power. ...the deployment of sexuality, on the other hand, engenders a continual extension of areas and forms of control. (Foucault, 1990, p. 106)

We may connect Foucault's sexuality, the deployment of alliance over female's virginity or chastity, to Lacanian object petit $a$ : via the control over female's sexuality, the marriage system can successfully operate in society. Thus, the family is an important site for the sexual deployment because "it conveys the law and the juridical dimension in the deployment and the intensity of sensations in the regime of alliance" (Foucault, 1990, p. 108). Being a privileged point of development in the family, the female's sexuality, functioning as "an obligatory locus of affect, feelings, love” (Foucault, 1990, p. 108), becomes the very object structured by male's fantasy. It explains why Alibius worries about his wife's chastity, Alsemero anxiously tests on Beatrice's virginity, and De Flore obsessively craves for and ravishes over Beatrice's body. William Naphy tells us: "In the technical understanding of the law, rape or any violent sexual assault was a very serious crime indeed” (p. 81). However, 
the key problem is "conviction": how do we make sure the sexual intercourse a sexual assault?

\section{Rape and Social Control}

It is impossible for Beatrice to accuse De Flores' evil conducts over her after the death of the expected husband Alonzo. She says:

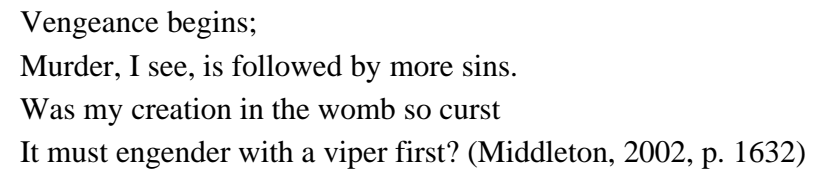

"It is important to remember," Naphy puts it, "though, that rape and sexual assault could result in severe punishment despite the lack of forensic evidence or cultural views tolerating fairly general sexual harassment of women” (Naphy, 2004, p. 93). What De Flores encounters is a very severe penalty. Rape itself is indeed a crime as social transgression, for it is "sufficient to ruin a woman's value as a commodity in the marriage market" (Burks, 1995, p. 764). In the English society, sexual ravishment is a deed identified as a crime against family property. Burks continues: "Rape is not so much a physical as a social threat to women, and it is not awful because of the emotional devastation inflicted on her, but on account of the distress it causes her family and peers" (p. 765).Therefore, what rape ruins is not only the victim's reputation but also deprivation of the advantage of her family in marriage bargaining. It undermines the social stability because "ravishment was viewed by the law as a crime inspired by a desire to move up the social ladder” (p. 765). Whether many rapists successfully received money or climbed up the social ladder in the society, there was also a strong threatening to the social order by sexually exploiting women.

Knowing that she will be degraded and loses her marriage to Alsemero, Beatrice has no choice but fake - first, she enacts the symptoms on the testing liquid, and, second, she replaces herself with Diaphanta at the night after the marriage banquet. Thus, we need to ask: is this play about the danger of women's desire or it is about women's ability to pretend? Which of the both causes more anxiety from men?

Garber suggests that female jouissance remains an unknown territory to male’s comprehension:

Woman’s orgasm if Freud's “dark continent,” as well as Mizaldus's "secret of nature,” Female pleasure is the unknown and unknowable, the other, less masterable and controllable answer to the question Freud poses over and over again, in different forms, throughout his work: “What does a woman want?” (Garber, 1996, p. 359)

Here, women sexual pleasure is a secret to herself where the discourse of male's knowledge builds. It is no doubt that the discourse of knowledge is power related, and it "can be both an instrument and an effect of power, but also a hindrance, a stumbling-block, a point of resistance and starting point for an opposing strategy" (Foucault, 1990, p. 101). Alsemero, a scholar, presents his power not only over his future wife Beatrice but is empowered by the knowledge of "Secrets in Nature." The more power he exerts, the more blind point betrays. Relying on the power of knowledge, he is deceived by Beatrice's false symptoms on the virgin text. Also, Beatrice reverses the core of the discourse by fake reactions.

How can a male understand "what a woman wants"? Ovid's story about Tiresias, who is asked whether men or women have greater sex pleasure, is the same kind of question. Being able to both male and female, Tiresias is involved between the dispute of Juno and Jove. Tiresias irritates Juno and is struck blinded by answering that 
women have more sexual pleasure. Why is Juno angry with his answer? Does her pleasure is shameful or "because a woman's pleasure is her secret—and her power?" (Garber, 1996, p. 360) The secret pleasure of a woman is the very core dominates a man's expectations, and it is also the power to manipulate a man's fantasy. "Women’s sexuality was," Burks argues, "indeed, a puzzle akin to the destabilized image of the transvestite player" (p. 780). Through her false reactions on medicine, Alsemero is lulled in the structure of his fantasy and deceived by Beatrice's changeling on his bed. Thus, Beatrice-Joanna is at last known to be 'the changeling," a whore masquerading as a bride, an actress acting the false appearance. Žižek tells us how the role of fantasies operates:

This role of fantasy hinges on the fact that "there is no sexual relationship", no universal formula or matrix guaranteeing a harmonious sexual relationship with one's partner: because of the lack of this universal formula, every subject has to invent a fantasy of his or her own, a "private" formula for the sexual relationship—for a man, the relationship with a woman is possible only inasmuch as she fits his formula. (Žižek, 1997, p. 7)

Alsemero is fooled because a woman's sexuality is unknown to his perceptions, and only by medical liquid, he can identify a virgin, a figure always-already fits into his constitutive fantasy. In this sense, he is wronged by his own eyes and fails to check as Beatrice tells him in the beginning. In addition, the desire of controlling female's pleasure reflects the man's thirst for power. Beatrice-Joanna's father is able to assign her marriage because he represents the patriarchal power in the family. Alsemero tests her because he is anxious to know if her body is intact, and, also, his medicine exhibits the power of a husband over the wife. What triggers De Flores' desire is surely Beatrice's virginity. Doesn't his ravishment both show his power over the lady and class transgression at the same time? According to Lacan, male's sexual pleasure is always accompanied by phallic function ${ }^{2}$, which represents a symbolic order in his perceptions. De Flores' transgression follows a pervert mode to regain his castrated excess in an obscene way. His manipulation over Beatrice-Joanna presents the ugliness to destabilize the social morality. He tells Alsemero: "Yes, and the while I coupled with your mate/ At barley-break; now we are left in hell” (Middleton, 2002, p. 1637). Discerning De Flores’ ugliness, his psychological mode fits into Lacan's pervert, who refuses to hand the pleasure over. In other words, he is convinced that his own pleasure is equivalent to pleasure to the Other.

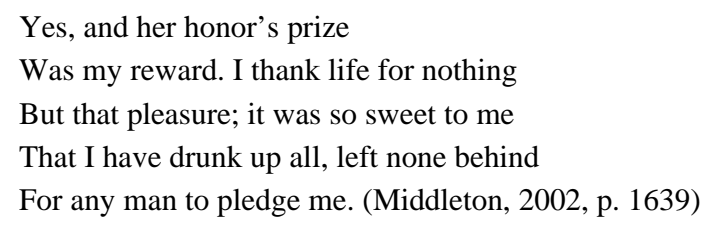

What he wants is a totally indulgence into his jouissance, a pleasure refusing the castration of the Other qua social codes. On the one hand, he refuses to disavow his desire (pleasure) under the social prohibitions that it makes him a horror figure in the society. On the other, because he rejects to be castrated (as a servant, he is powerless), his manipulation over Beatrice is imaginative involved-fantasying his phallic expenditure is able to escape the castration of the social orders. Also, the pervert subject believes that he withholds the Other's jouissance. De Flores believes that he proffers Beatrice-Joanna the jouissance by "endlessly" ravishment.

2 Lacan notes: "there is no chance for a man to have jouissance of a woman's body, otherwise stated, for him to make love, without castration (à moins de castration), in other words, without something that says onto the phallic function” (Seminar 72). 
However, his service turns Beatrice into a murderess and reward into a whore: “I have kissed poison for’t, stroked a serpent” (Middleton, 2002, p. 1631).

Alsemero complains to Beatrice after the confession: "Oh, thou shouldst have gone/ A thousand leagues about to have avoided/ This dangerous bridge of blood! Here we are lost” (MIddleton, 2002, p. 1633). It is as Judith Haber tells us that The Changeling "articulates just such a moral sequence" (Harber, 2003, p. 90). The sequence of crime, murder and adultery, reveals not only Beatrice’s ignorance but also her “inward evil” (p. 90). Her first wrong step is the disobedience against her father's marriage order. Her moral ignorance and blindness5 render her a murderess. Paying for the price of murder, for her, "[I] could not choose but follow" (Middleton, 2002, p. 1631). Beatrice's tragedy is not merely about moral problems. Her tragic outcome implies her inability to escape the male's sexual expectations. Michael Andrews tells us: "A sexual battleground important not because of her own intrinsic power, but rather as a mark of the father's power” (Andrews, 1971, p. 380). However, the implication within The Changeling is not only the father's power over the daughter. It is also the power of knowledge speculating the female sexuality as well.

\section{Conclusion}

At the end, De Flores still possesses a miscomprehension upon a woman's body: "I am so stout yet,/ And so, I think, that broken rib of mankind” (Middleton, 2002, p. 1635). He suggests that Beatrice is as a descendant of Eve who has been taken from Adam's rib and has to be responsible to Adam's fall. If Eve needs to be blamed for her temptation to Adam, we are on a respect to see Adam's incapability to resist temptations. The tragedy in Middleton and Rowley's The Changeling, on the one hand, tells the audience the danger of a woman's desire if it is not suppressed. At the same time, it reveals male's anxiety to the female's sexuality which is un-masterful and uncontrollable: where the power goes, the weakness explored. Indulging within his knowledge about the female's sexuality, Alsemero is already deceived by the appearance of Beatrice's faking. De Flores is also caught into his masturbation fantasy, in the way of a pervert, believing that his transgression is a source of pleasure, eschewing the social regulations. Seducing Beatrice by means of rape, he believes her jouissance is obtained by his offering, which is not a real pleasure but a "shame" that finally destroys her. Beatrice's horrifying tragedy reveals the male's fantasy and expectations on the female's sexuality in the Renaissance society. Her virginity not only turns herself a commodity in the marriage market but also makes her a prey to the pervert De Flores. Sexuality qua the object petit a has long been a core of a woman's body. "The good woman is pure in body (that is, nonsexual); the bad, impure (that is, sexual)” (Robin, 1997, p. 168). Thus, sexuality of women becomes the most anxious for men to control in the Renaissance society. Beatrice-Joanna's tragic outcome reveals the inhumane situation for women that either they are a commodity in the marriage alliance or a whore. While their virginity is seen valuable in marriage bargaining, their sexuality, however, always-already eludes the frame of masculine domination.

\section{References}

Andrews, M. C. (1971). "Sweetness” in "The Changeling”. The Yearbook of English Studies, 1, 63-67.

Bevington, D., Engle, L., Eisaman, K., \& Rasumsseneds, E. (2002). English renaissance drama: A norton anthology. New York: Norton.

Burks, D. G. (1995). "I’ll want my will else”: The Changeling and women’s complicity with their rapists. ELH, 62(4), 759-90. Engelberg, E. (1962). Tragic blindness in The Changeling and Women Beware Women. Modern Language Quarterly, 23(1), 20-28. 
Engle, L. (2002). The changeling. English renaissance drama: A norton anthology. New York: Norton.

Foucault, M. (1990). The history of sexuality: An introduction. New York: Vintage.

Garber, M. (1996). The insincerity of women. In M. De Grazia, M. Quilligan, and P. Stallybrass (Eds.), Subject and object in renaissance culture. London: Cambridge UP.

Haber, J. (2003). I(t) could not choose but follow: Erotic logic in The Changeling. Representations, 81(1), 79-98.

Lacan, J. (1999). On feminine sexuality: The limits of love and knowledge (B. Fink, Trans.). New York: Norton.

Middleton, T., \& Rowley, W. (2002). The changeling. English renaissance drama: A norton anthology. New York: Norton.

Naphy, W. (2004). Sex crimes: From renaissance to enlightenment. Stroud: Tempus.

Robin, D. (1997). Woman, space, and renaissance discourse. In K. Barbara and P. Gold (Eds.), Sex and gender in medieval and renaissance texts: The latin tradition. New York: State U of New York P.

Žižek, S. (1993). Tarrying with the negative. Durham: Duke UP.

Žižek, S. (1996). "I hear you with my eyes”; or, The invisible master. In R. Salecl and S. Žižek (Eds.), Gaze and Voice as Love Objects. Durham: Duke UP.

Žižek, S. (1997). The plague of fantasies. London: Verso.

Žižek, S. (2002). The real of sexual difference. In S. Branard and B. Fink (Eds.), Reading Seminar XX. New York: U of New York. Žižek, S. (2008). Interrogating the real. New York: Continuum.

Žižek, S. (2017). Incontinence of the void: Economico-philosophical spandrels. New York: MIT Press. 